\title{
DNA Chips in a Blueberry Dip
}

\author{
Daniel Gaudet ${ }^{a, b}$ \\ aUniversity of Montreal Preventive and Community Genomic Medicine Center, ${ }^{b}$ Corporation for Research and \\ Action on Hereditary Diseases, Chicoutimi, Québec, Canada
}

On June 20-22, 2000, the Saguenay-Lac St. Jean region (Québec, Canada) hosted the first international conference on community genetics. Titled 'From DNA to the Community', this conference was organized by the Corporation for Research and Action on Hereditary Diseases (CORAMH) and Health Canada, with the World Health Organization's (WHO) co-sponsorship and the support of the Applied Genetic Medicine Network (RMGA) of the Fonds de la recherche en santé du Québec (FRSQ). This meeting's participants included researchers and community genetics specialists, decision makers and administrators from the health care network, people associations and community representatives, health professionals and professional corporate bodies, ethics and law specialists, representatives from political parties, as well as communicators and representatives from the news media. The diversity of people and organizations present at this meeting illustrates the complexity of factors involved in the integration of genetic knowledge, from DNA to people, families, communities and mankind. Several grounds have motivated CORAMH and its partners to hold such a conference in Saguenay-Lac St. Jean. For one, this region's experience in community genetics extends over several decades. In addition, many important genetics and genomics projects currently in progress in Québec and Canada, profit by the experience of this region and of CORAMH. However, experience in genetics is not the only asset that Saguenay-Lac St. Jean can and wishes to share with other worldwide communities. Suffice it to say that this region is known throughout the world for the beauty of its wild natural environment, its French flavor, its friendliness, and ... its blueberries.

Saguenay-Lac St. Jean is a highly wooded region, carved around the St. Jean lake and Saguenay fjord. EuroCaucasian populating began after 1838 , mainly from mi- gratory movements from the Charlevoix region. This colonization took place further to the association of 21 owners and tax paying citizens from Malbaie parish, who bought shares in the Hudson Bay company, in order to obtain a license for pinewood development on the king's lands in Saguenay. This grouping of shareholders, known under the name of 'Société des 21', sent a first party of 27 people to Anse St. Jean, in April 1838. In June of that year, a group of 14 men landed at the southeast extremity of the Baie des Ha! Ha! During winter 1838-1839, the region already counted 6 permanent colonies. At that time, blueberry was just an anonymous fruit, lost on the King's vast domain. A few decades later, it became the symbol of the entire Saguenay-Lac St. Jean region.

This coronation ensues from the fortuitous encounter of an electromagnetic radiation and a plant cell, on a stormy night of spring 1870 . That night, lightning struck a population of gray pines, and within a few hours, fire devastated more than 100 kilometers of the Saguenay-Lac St. Jean forest, from St. Félicien up to the mouth of the Saguenay river. The ecological equilibrium was severely disturbed by the fire. The density of the biomass, the $\mathrm{pH}$ and the ground's temperature revealed a new climate promoting outbursts of blueberry populations. In the same field, a mass of spruces replaced the devastated gray pines, consequently modifying the region's socioeconomical vocation: beam cutting and shipbuilding declined, giving way to soft wood cutting, substratum of paper mills, appearing soon after 1890 . The stream of events that brought 'wood pulp' and 'blueberry pie' to become vectors of socioeconomic changes in Saguenay-Lac St. Jean therefore derives from a point mutation in the ecosystem, on one stormy night. In the case of several genetic disorders, the scenario follows about the same course: an

\begin{tabular}{ll}
\hline KARGER & ( 2001 S. Karger AG, Basel \\
Fax +41 613061234 & 1422-2795/00/0033-0097\$17.50/0 \\
$\begin{array}{l}\text { E-Mail karger@karger.ch } \\
\text { www.karger.com }\end{array}$ & $\begin{array}{l}\text { Accessible online at: } \\
\text { www.karger.com/journals/cmg }\end{array}$
\end{tabular}

Daniel Gaudet, MD, PhD

CORAMH and University of Montreal Preventive and

Community Genomic Medicine Center, 305, St.Vallier Street, Postal Box 257

Chicoutimi, Quebec G7H 5 H6 (Canada)

Tel. +1 418541 1077, Fax +1 418541 1116, E-Mail dgaudet@saglac.qc.ca 
electromagnetic radiation interferes with the magnetic moment of the phosphorus and modifies the quantum of energy of a DNA molecular sequence. This little DNA sequence change can obviously produce an important impact on a community as well.

In the early 1900s, while the blueberry population was exploding in the Saguenay region, the theory of Mendelian genetics was called in question on the basis that simple, discrete inheritance patterns did not apply to variations typically seen in nature. After several years of crabbed and intense discussions, the issue was theoretically resolved with the understanding that Mendelian factors could give rise to complex and continuous traits. Knowledge acquired during the following decades brought the discussion beyond Mendelian genetics and monogenic hereditary diseases, so that today, with the development of a variety of new analytical methods, new technologies (including micro arrays or DNA chips), the advent of dense genetic linkage maps and the identification of the human genome, genetic dissection of complex traits has clearly been activated. While this effort will shed light on the genetic determinants of health and diseases, it will also generate an immense output of new knowledge. The emerging issues turn out to be relevant, not just regarding the acquisition of genetic knowledge but also the development of new fields of research in order to understand and use such knowledge (functional genomics, proteomics, pharmacogenomics and bioinformatics for example ). We are now faced with the task of defining priorities, to establish criteria and modalities for transferring this knowledge to health professionals, people, families, communities and populations and to develop tools needed for using genetic knowledge in disease prevention, health promotion and health surveillance. 'Community genetics', as a science, has certainly something to do with this challenge, since it hinges around three interdependent activity processes, which are continuous and interactive with one another: (1) acquisition of knowledge, (2) transfer of this knowledge, and (3) application of this knowledge to people, families, communities and populations.

Although the term 'community genetics' first appeared about 15 years ago, the concept is not a new one. In fact, many experiences in transferring genetic knowledge to communities or populations have been taking place in many countries, and for several decades. It is obvious that these experiences, most often relating to monogenic diseases, will help ensure transition to community genomics. Conversely, the identification of the human genome will undoubtedly serve as a development lever for community genetic strategies applied to monogenic disorders. In this post-genomic era, we are now beginning to explore new medical and social frontiers and community genetics is thus inevitably about to explode.

This special issue of Community Genetics encloses papers covering last June's conference in Saguenay, namely the detailed program presented in Community Genetics' June issue. The following articles present several worldwide experiences in community genetics: from urban or rural environments, from the industrialized world and from developing countries. Some relate to tools or different dimensions of the genetic knowledge transfer to communities, including ethical, legal, geographical and social aspects. There are also examples of community actions in genetics, resulting from the initiative of people associations, such as the US Genetic Alliance and, of course, CORAMH's experience, presented herein.

National and international experts who took part in the Jonquière conference each provided their own definition of community genetics. Primary concepts emerging from these definitions have been compiled in a letter to the editor, also displayed in this issue. The evolution of community genetics' definition and related concepts will be followed through time, in an important project called ECOGENE-21. Number ' 21 ' in this project's title is intended to be a tribute to the above-mentioned 'Société des 21 ', as well as a recall of what awaits us in this new 21 st century. The ECOGENE-2 1 project is also presented in one of the papers of this special issue.

In conclusion, this special issue is being published at a time when genetics is becoming increasingly popular. It becomes news material for the media. It is advertised on supermarket and drugstore shelves, and it is becoming increasingly important in the medical world and in public health. In this regard, community genetics is anchored somewhere between genetic knowledge and the power to use it. Sort of between the bark and the tree, insofar as knowledge is a cumulative heritage which can be shared and transmitted through time and generations. Since the beginning of human life on earth, human genetic material has been transmitted from generations to generations and, by its own nature, belongs to mankind. In the postgenomic era, knowledge on this material and on the outcomes of its expression increases rapidly, but becomes more complex as well. Scientific, economic, social or clinical methods for the transfer of this knowledge to people and communities around the world are also complex; they compel us to appeal to wisdom, integrity and dialogue. It is not always easy, but this is how we must proceed if we want to give our children and future generations the best possible world to live in. To me, it suggests that in this DNA chip era, there is still a lesson to be learnt from Saguenay's blueberries ... 